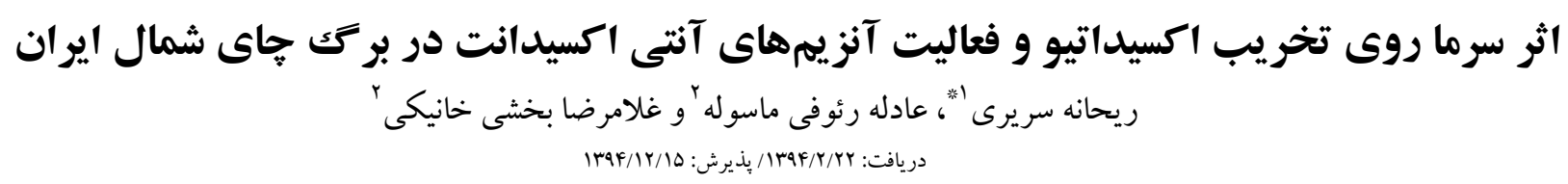

وازههاى كليدى. استرس سرمايى، آسكوربات براكسيداز، براكسيداسيون لييدى، يروتئين ضديخ، سويراكسيد ديسمو تاز، كاتالاز

\title{
The effect of cold temperature on oxidative damage and activity of oxidative enzymes in tea leaves from northern Iran Reyhaneh Sariri ${ }^{*}$, Adeleh Raeofi Masooleh ${ }^{2}$ and Gholam Reza Bakhshi Khaniki ${ }^{2}$ Received 12.05.2015/ Accepted 05.03.2016
}

\footnotetext{
${ }^{1}$ Department of Biology, Faculty of Sciences, University of Guilan, Rasht, Iran ${ }^{2}$ Department of Biology, Tehran Shargh Branch, Payam Nour University, Tehran, Iran *Correspondent author: sariri@guilan.ac.ir
}

\begin{abstract}
Tea was planted in Lahijan by Kashefalsataneh in 1930. The main concern about important commercial plants such as tea is the formation of ice crystals in low temperatures. This can damage the live cells leading to lowering the quality of the plant and eventually its death. Formation of reactive oxygen species (ROS) and oxidative stress is the result of various environmental stresses leading to freezing. Investigating the variations in any of these factors could help to understand the mechanism of freeze resistance in ever-green plants. The aim of the present research was to investigate lipid peroxidation, the presence of antifreeze protein and variations in the activity of some antioxidant enzymes, including superoxide dismutase (SOD), ascorbate peroxidize (APX) and catalyse (CAT) in tea leaves subjected to $20,0,-2,-5$ and $-8^{\circ} \mathrm{C}$ in tea leaves from the north of Iran. The results showed formation of an antifreeze protein with $\mathrm{MW}$ of about $20 \mathrm{KD}$ in response to cold stress. It was also found that the activity of SOD, APX and CAT increased in tea leaves due to cold stress. The activity of SOD increased down to $-8^{\circ} \mathrm{C}$. APX and CAT increased their activity down to $-5^{\circ} \mathrm{C}$. On the other hand, the lipid per oxidation factor, MDA, was also elevated in response to the cold stress.
\end{abstract}

Keywords. antifreeze protein, ascorbate peroxidase, cold stress, catalyse, lipid per oxidation superoxide dismutase 
سرمازدگى و اثر مخرب آن بر گياه مى تواند تا حد زيادى زمينه

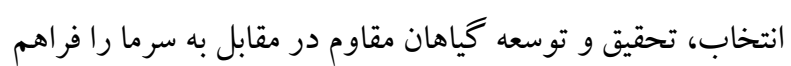

آورد (García-Varela \& Fermín, 2003).

بوته جاى معمولاً به عنوان گياه هميشهسبز حساس به سرما طبقه -

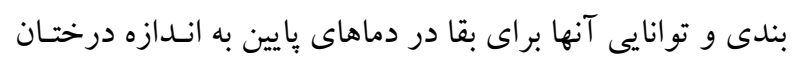

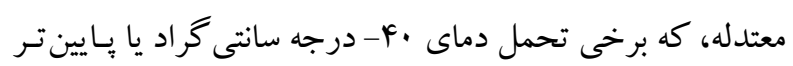

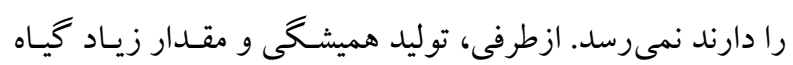

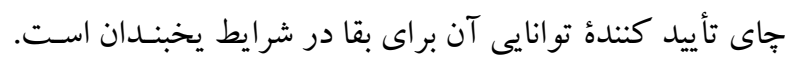

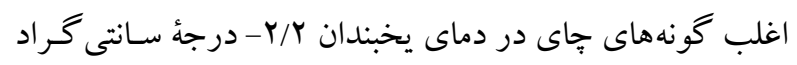

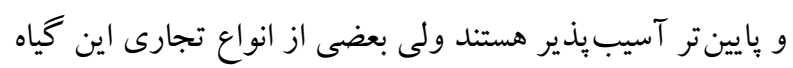

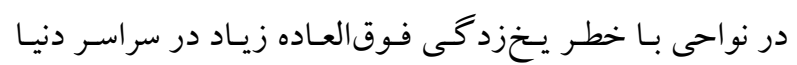
برورش داده مىشوند (Almeida et al., 1999).

براساس رفتار درمقابل يخزدگى دو دسته بافت جوبـى وجـود

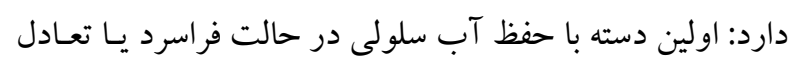

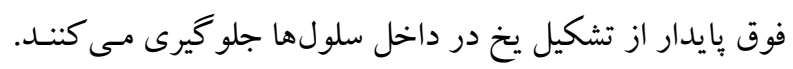

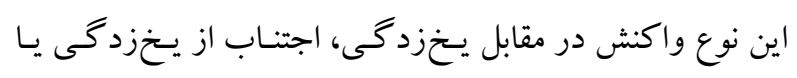
فراسردشـدن ناميـده ميىشود (George \& Burke, 1984).

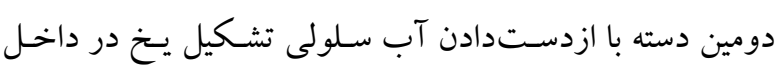

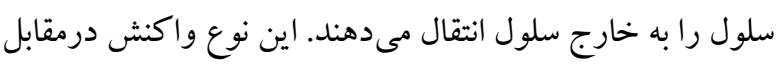

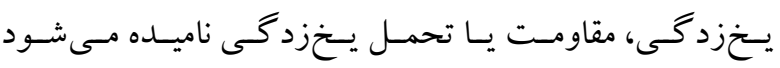

.(Cattivelli, 2011)

در جاى، حفاظت سرمايى ازطريق اجتناب از سـرماى غيرفعال و

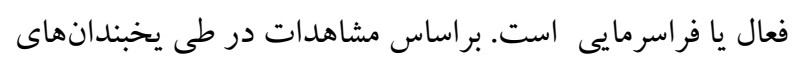

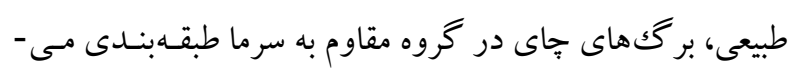

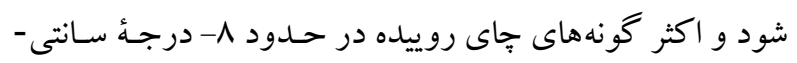

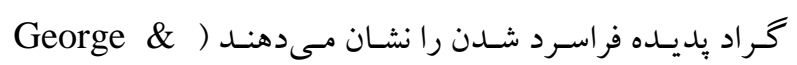

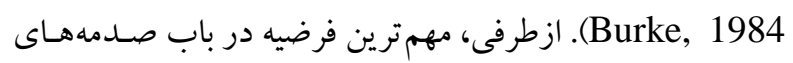

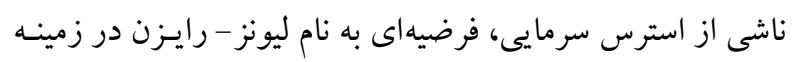

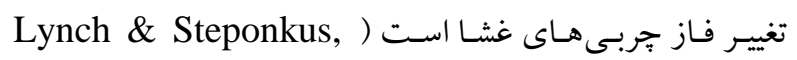
1987). براساس اين فرضيه اولين حس كننده حرارتى در سلول

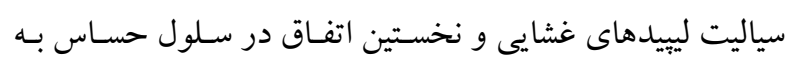

لينه نخستينبار سال هrVI ميلادى در جلد اول كتاب طبقهبندى

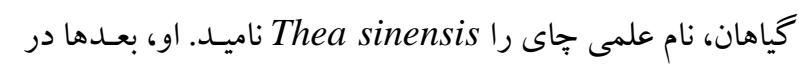
جلد دوم كتابش از جاى با عنوان Camellia sinensis نام برد.

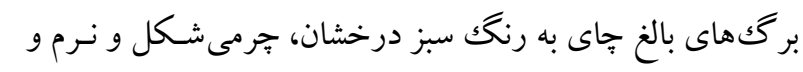

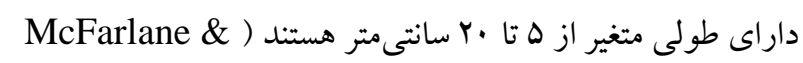
McFarlane, 2004

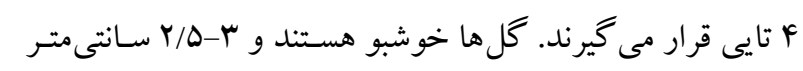

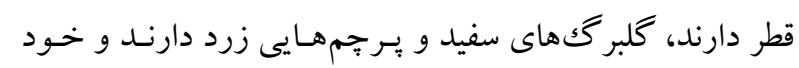
عقيم اند.

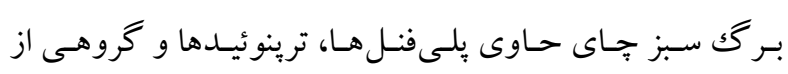

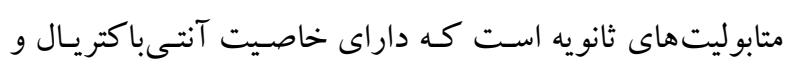

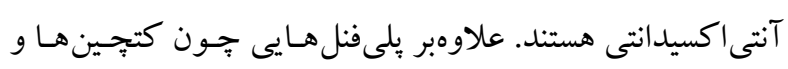

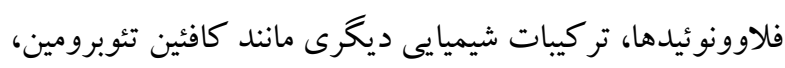

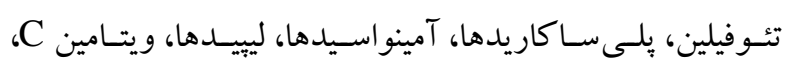

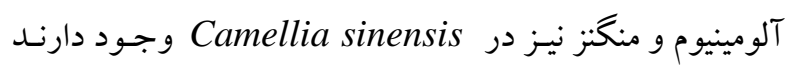

.(Graham, 1992)

بسيارى از گ نههاى گياهى، بهويزه گونه هاى مناطق گرمسيرى و

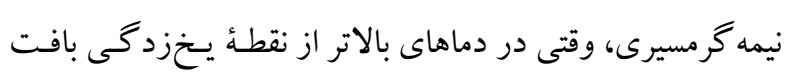

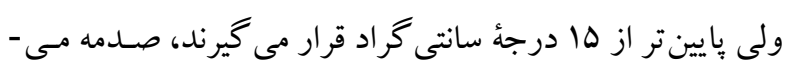
بيند و دجار سرمازد گحى مس شوند (Almeida et al., 1999).

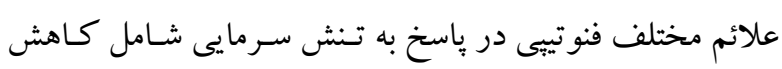

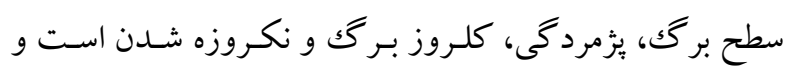

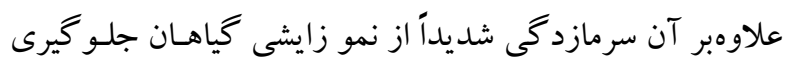

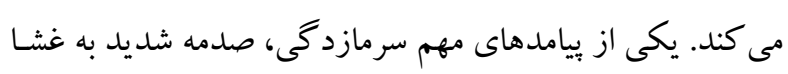

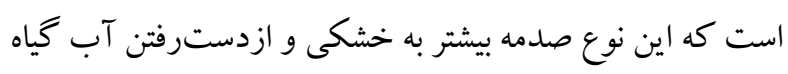

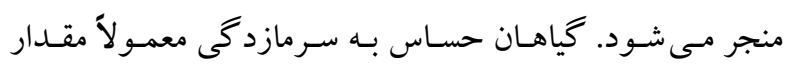

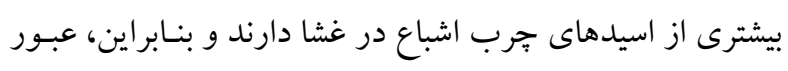

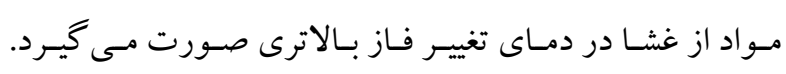

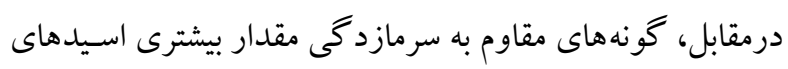
جرب غير اشباع در غشاى سـلولى دارنـد و دمـاى تغييـر فازشـان

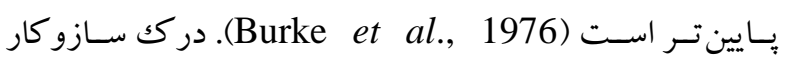


آمين تتراستيكك اسيد (EDTA)، بلسى وينيـل بيروليـدون (PVP) هيدروزن يراكسيد، آسكوربيكك اسيد (ASA)، متيونين (Met)،

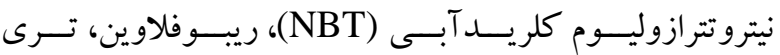
كلرواسـتيكك اسـيد (TCA)، افسـفريك اسـيد، كلو تار آلدئيـد، سديم استات، سديم تيوسولفات، نيترات نقره، فرمالدئيد، سديم

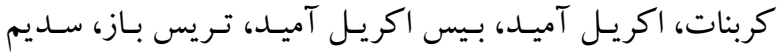
دودسيل سولفات (SDS)، كلريدريك اسيد (HCl)، كلايسين (Gly)، كليسرول، برومو فنل بلو (BFB)، آمونيم بر سـولفات و

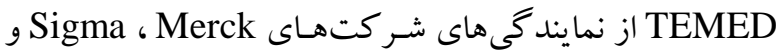
Fluka

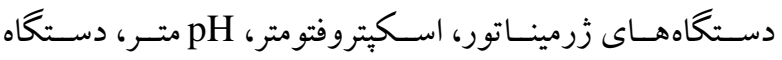
انكوباتور ويزه سـرمادهى، الكتروفورز، سـانتريفيوز يخجِالدار،

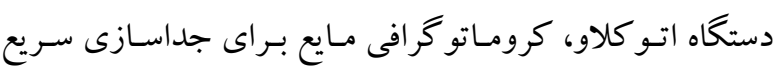

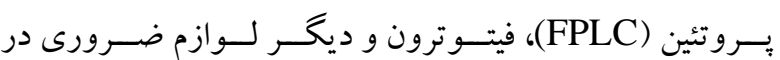

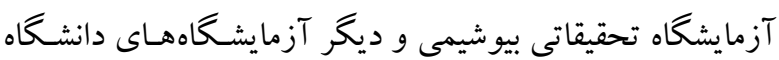
گيلان مورد استفاده قرار گرفتند.

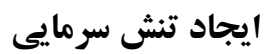

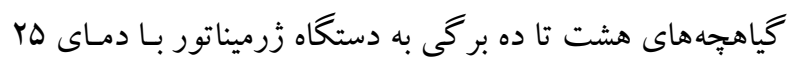

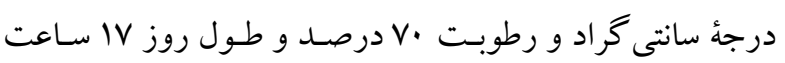

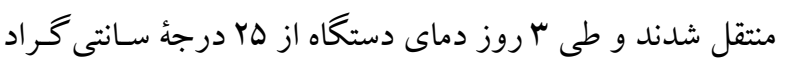

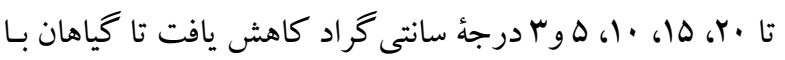

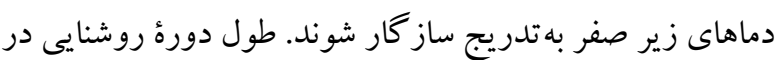

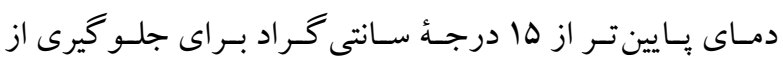

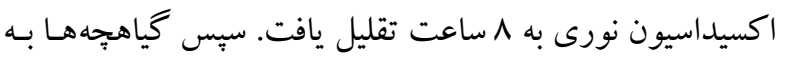

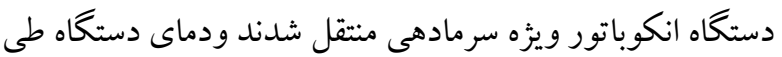

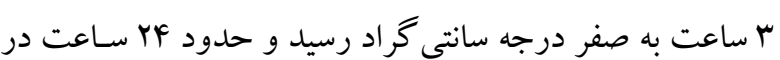

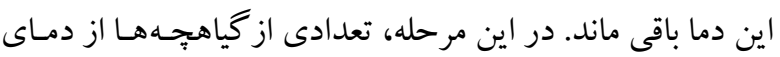

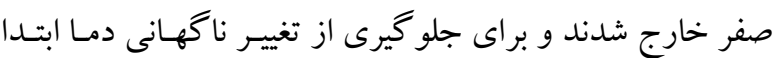

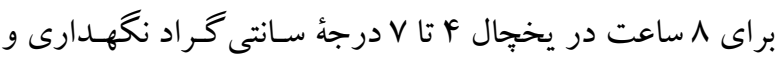
بعد به فيتوترون ها درجهُ سانتى گحر اد بـود منتقل شـدند. بـسـاز

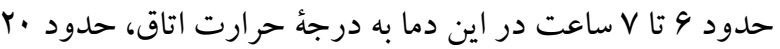

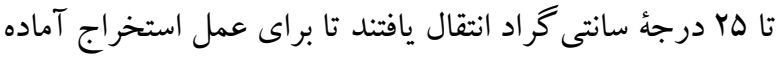

سرما هنغـام قرارگحرفتن، تغييـر حالـت در نظم مولكـولى تودهه جربى هاى غشايى است.

افزايش مقدار و ميزان فعاليت آنزيمهـاى آنتى اكسيدانتى مانــد سويراكسيد ديسموتاز (McKersie et al., 1993)، كاتـالاز (Prasad, 1997; Sala \& Lafuente, 1999)

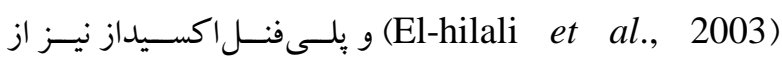

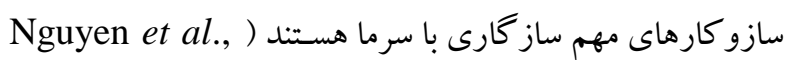

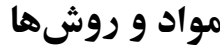

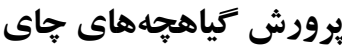

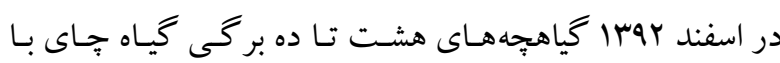
مقاومت سرمايى متوسط از جند مزرعه جاى لاهيجان تهيه شدند.

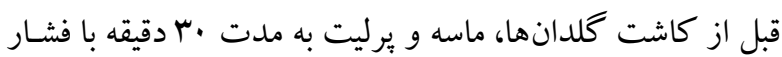

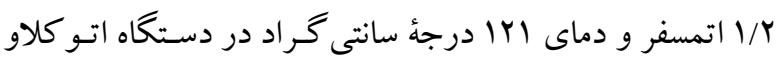

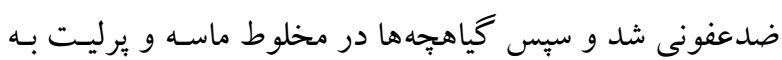
نسبت ا: F كاشته شدند. بـراى اينكـه گياهجهـهـا كـه در دمـاى معمولى كاشته شده بودند دجـار شـوك يـا استرس سـرمايى يـاـ

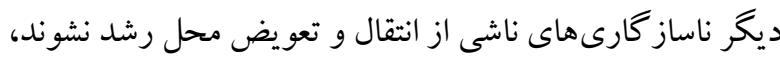

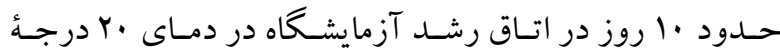

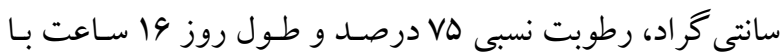
شـدت نسورى برابـر حسدود ..191 لـو كس (·rميكرومسول در

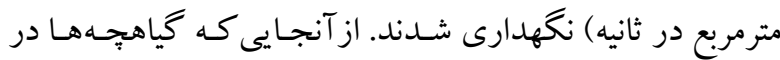
خاكك سبك كاشته شده بودند و اين خاكك نيز قابليت نخهدارى آب را براى تغذيه گياهجهها نداشت، از محلول هو كلند (بهازاى هـر ليتر مـاكرو يـكك ميلىليتر ميكـرو) بـراى آبيـارى و تغذيـه

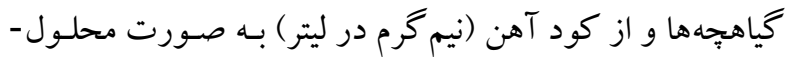

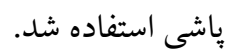

مواد شيميايع و دستغاهها كوماسى بريليانـت بلـو جسى ه广، منسو و دى بِتاسـيم هيـدروزن

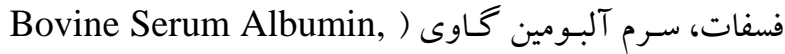

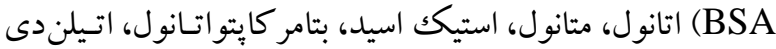




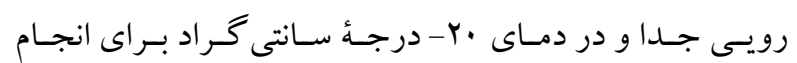
آزمايش هاى بعدى نخهدارى شد.

\section{تهيةً بافر فسفات جهت استخراج}

pH=7 براى استخراج بـروتئين از بـافر فسـات · r ميلى مـولار استفاده شد و براى تهيئ بافر آنزيمى، ، ․ الميلىليتر از بافر مذكور

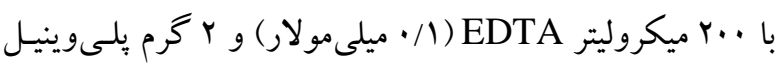
ييروليـدن (PVP) مخلـوط و pH آن روى V تنظـيم شـد. بـافر تشخيص :بروتئين نيـز از انحـلال بس/، گـرم بتامر كايتواتـانول در

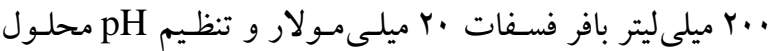
روى Vبه دست آمد.

\section{تعيين يروتئين كل عصاره به روش برادفورد}

در اين سـنجش، اتصـال كوماسـى بريليانـت بلـو بـهـ يـروتئين در

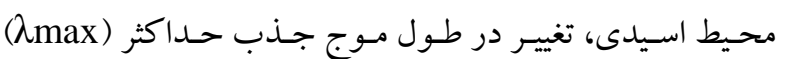

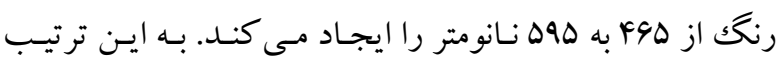
جـذب در هوه نـانومتر بـا غلظـت يـرو تئين رابطـه مسـتقيم دارد. مقدار كل يروتئين در هر نمونه ازطريق اندازه گيرى جذ ب بـ آنها در طول موج هوه نانومتر و با توجه به جذب استاندارد آلبـومين سرم (BSA) گاوى محاسبه شد (Bradford, 1976).

\section{سنجش فعاليت آسكوربات يراكسيداز}

بـراى بررسـى فعاليـت آنـزيم آسـكوربات براكسـيداز از روش (Bunkelmamm \& Trelease, 1996) استفاده شد. در عمل، · ․ ميلىليتر بافر فسفات • ه ميلىمولار بـا

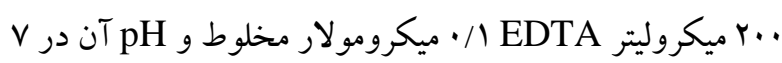

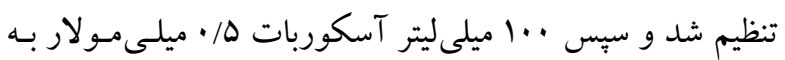
آنها اضافه شد. براى بلانكك نيز •هو ميكروليتر بافر آنزيمسى و •ه ميكروليتر از استوكك يراكسيد هيدروزن ريخته شد و در دستگاه اسيكتروفتومتر قرار گرفت. از طرفى، · به ميكروليتر بافر آنزيمى با ••ه ميكروليتر اسـتوك ير اكسـيد هيـدروزن و ·r ميكروليتـر از محلول حاوى آنزيم در كووت كوارتز نمونسه مخلـوط و جـذب

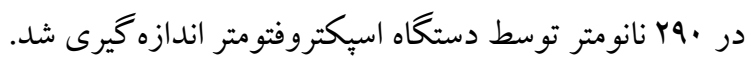

شـوند. ديخـــ تيمارهـاى سـرمايى نيـز در ب-و ه-و ^- درجـه

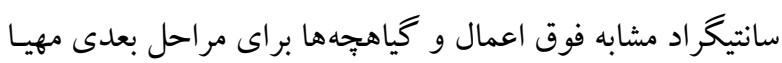

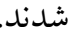

اندازهكيرى مقدار ير اكسيداسيون ليييدى

با توجه به اينكه مالون دى آلدئيد (MDA) بهمنزله محصول دوم يراكسيداسيون ليييدى، با تيوبار بيتوريك اسيد (TBA) واكسنش مى دهد، اين سـنجش بـا اسـتفاده از TBA و تـرى كلرواسـتيك اسيد (TCA) انجام شد (Tiu et al., 2009). براى تهيئ محلول بافر استوكك، به طور همزمان ه/ • گـرم TBA در • · ميلى ليتـر آب مقطر و •r گرم TCA در ·س ميلى ليتر آب مقطر حل شدند. سبس دو محلول با هم مخلوط شدند و حجم نهايى با آب مقطر به · · إيلى ليتر رسـانده شـد. . .9 ميكروليتـر از استوكك بـافر، حجم مسـاوى از ب/ه درصـد (TBA) و 9/0 درصـد (TCA) بـا

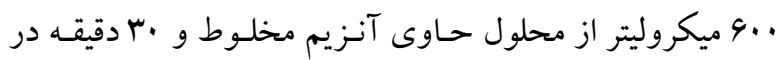

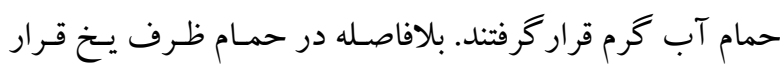
داده شد و سبس · ادقيقه در دمـاى F درجسه سـانتيخر اد بـا دور

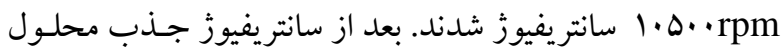
رويى بسه و · .4 نانومتر قرائت شدند.

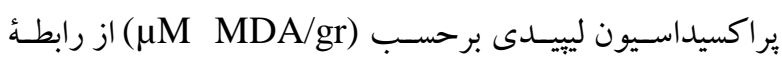

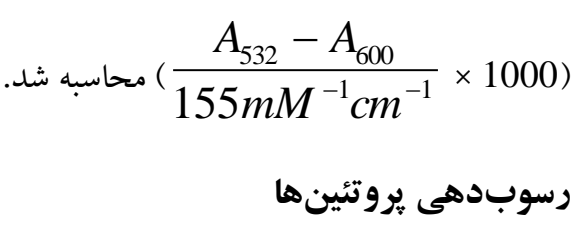
حدود ا گرم از بركَهاى سبز و تـازه بـه كمـك نيتـروزن مـايع

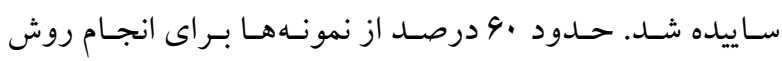
تشخيص بروتئين و ·f درصد نيز براى سنجش آنزيمسى استفاده شدند. . . ه ميكرومول (نسيم ميلى ليتـر) از بـافر مـورد نظـر (بـافر آنزيمى يا بـافر تشخيص بروتئينى) روى عصسارهُ برگى داخل ميكروتيوٍ اضافه شد و در سانتريفيوز يخجالدار و دماى صـفر

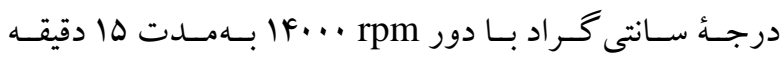
سانتريفيوز شدند. محلول رويسى بـا دقـت برداشـته شـد و بعـد از

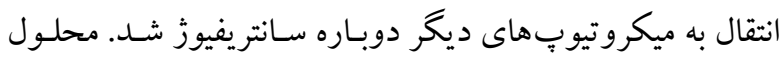


كروماتو گر افى FPLC با استفاده از دو سـتون دىاتيـل آمينو

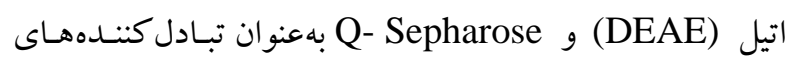

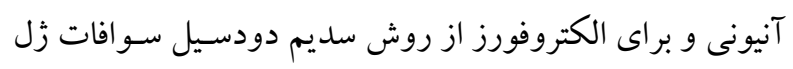

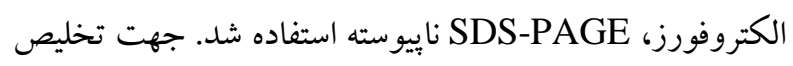

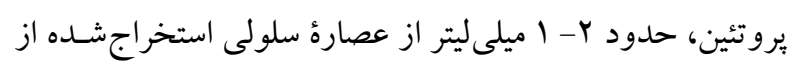

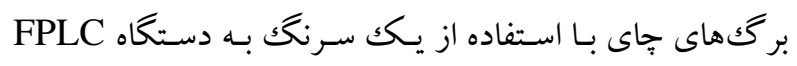

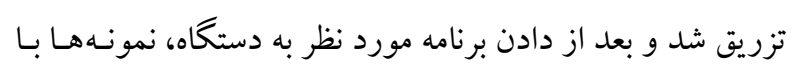
اعمال برنامه توسط دستخاه در ميكروتيو بِها جمع آورى شـدند.

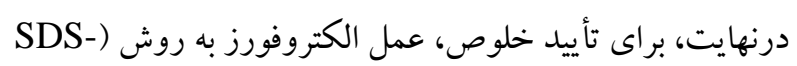

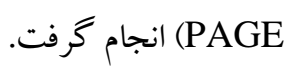

\section{يلى آكريل آميد زل الكتروفورز}

عمل الكتروفورز عمودى با استفاده از زل بالايى ه درصـد و زل

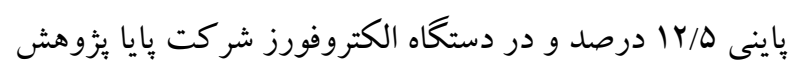

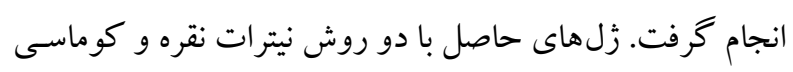

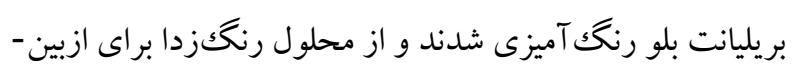
بردن رنغك زمينه زل استفاده شد.

\section{نتايج \\ يراكسيداسيون ليبيدى}

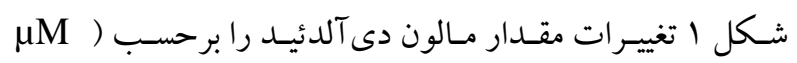

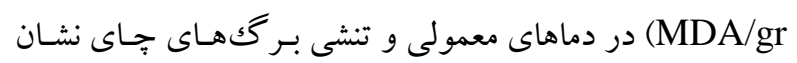

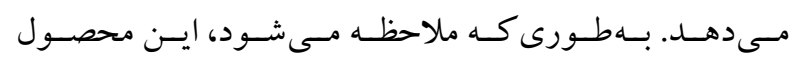

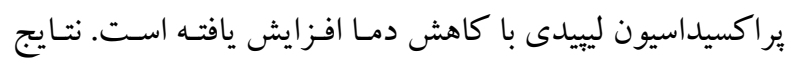

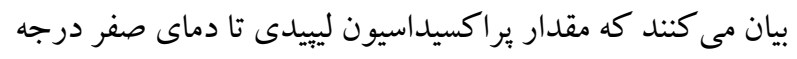
سانتى كراد كمتر است زيرا تا اين دما هر سه آنزيم آنتى اكسيدان

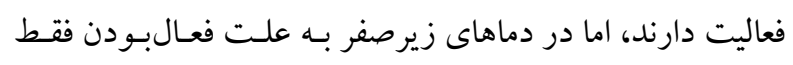

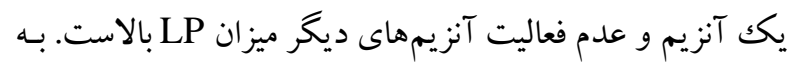

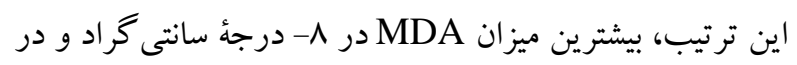
حدود YVV/ • ميكرومول بر خرم است (شكل ().

\section{سنجش فعاليت كاتالاز}

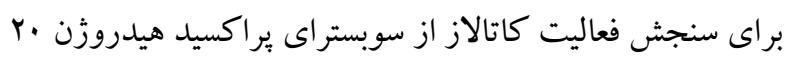

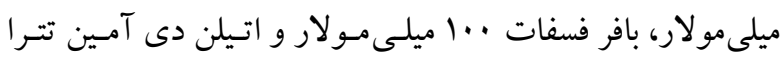

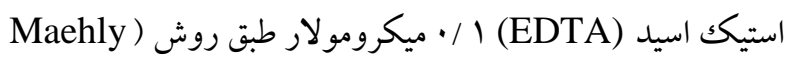

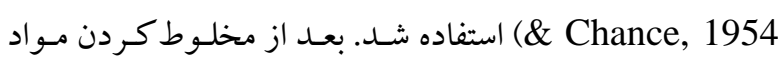

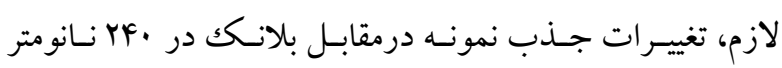

$$
\text { اندازه گيرى شد. تلغيترات }
$$

سنجش فعاليت آنزيم سويراكسيدديسموتاز براى سنجش فعاليت اين آنزيم از روش شرحدادهده با تغييرات

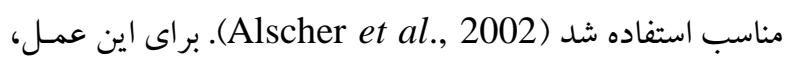

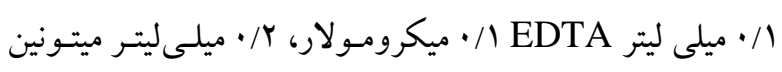

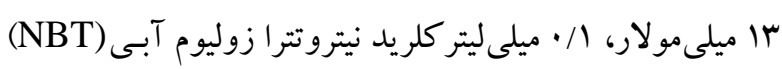

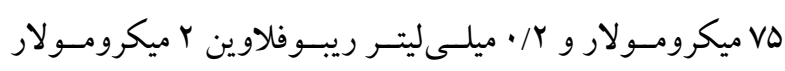

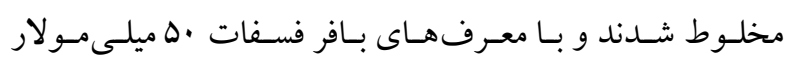

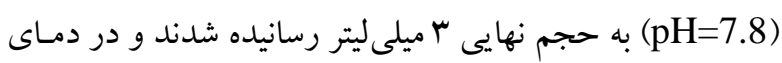

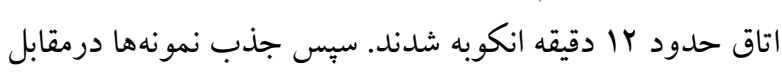
بلانكك در طول موج •وها نانومتر در زمان صفر و فو اصل زمانى يكك دقيقهاى تا با دقيقه اندازه كيرى شد.

تعيين فعاليت ويزه آنزيمى براى تعيين فعاليت ويزه آنزيمها از فرمول زير استفاده شد. Specific Activity (unit $/ \mathrm{mg})=\frac{\text { Total activity }}{\text { Total protein }}$

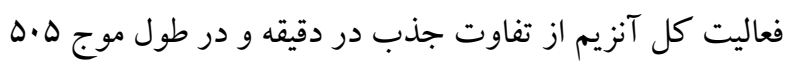

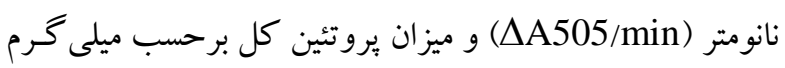

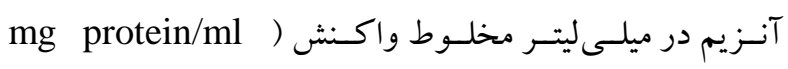
(reaction mix

\section{تخليص بروتئين ضديخ}

fast ) براى اين عمل از كرومـاتو گرافى اختصاصى يـروتئين هـا

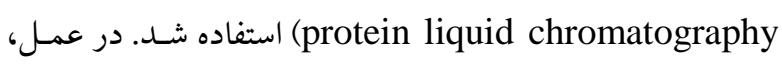




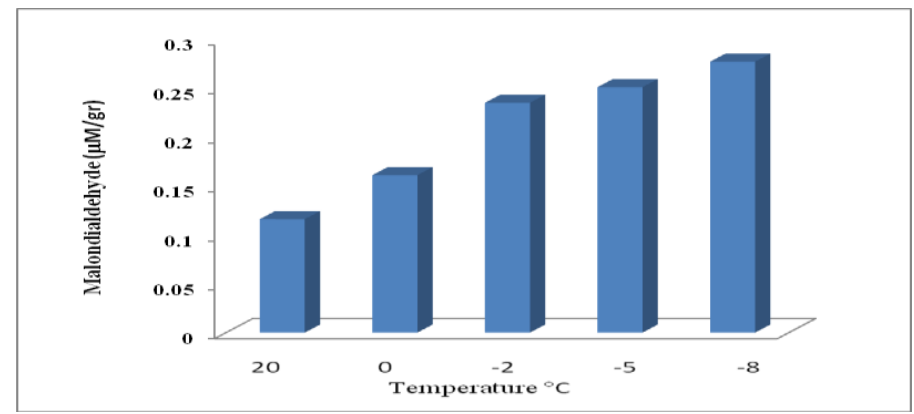

شكل ا- تغييرات مقدار مالون دى آلدئيد در دماهاى مختلف. تفاوت معنىدار بين مقدار مالون دى آلدئيد در دماهاى بالاى صفر با زير صفر مشاهده شد.

Fig. 1. Variations in malone dialdehyde at various temperatures. Significant differences were observed between concentrations of MDA at temperatures below and above zero degree of centigrade.

محاسبة فعاليت ويزه همه آنزيمهاى تحت بررسى يكسان در نظر

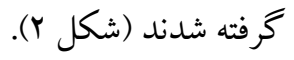

اندازه گيرى مقدار كل يروتئين در عصارة بركى جاى شكل ب نتايج حاصل از اندازه گيرى يـروتئين كـل را نشـان مسى دهد؛ بهطورى كـه در ايـن نمـودار مشـخص اسـت، مقـدار كـل برو تئين هاى بركَ جاى برحسب (mg/ml) نيز با كـاهش درجـه حرارت افزايش نشان داد و بيشترين آن در ^- درجهُ سانتى گر اد و بر ابر با (mg/ml) بوده. كفتنى است كه اين مقادير براى

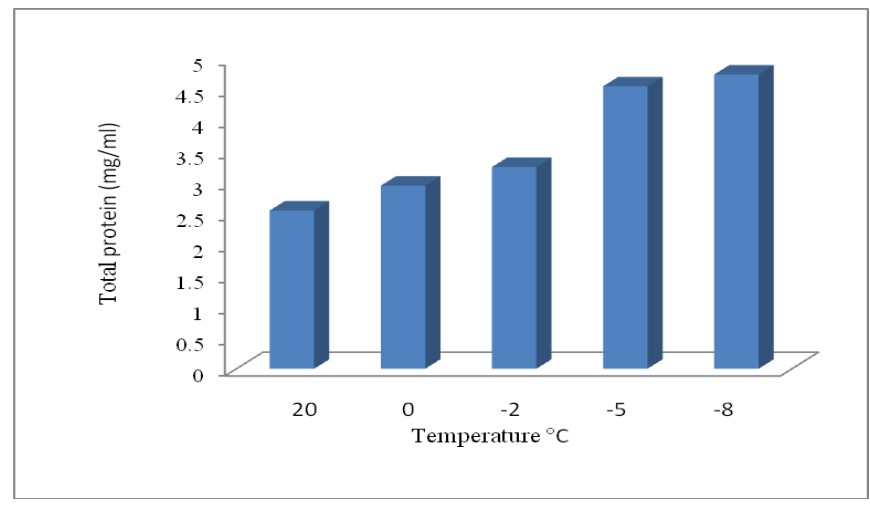

شكل r- تغييرات مقدار كل بروتئينها در عصارة بر گكاى جاى. تفاوت معنى دار بين مقدار برو تئين در دماهاى مختلف مشاهده نشد.

Fig. 2. Variations of total protein in tea leaf extracts at various temperatures. No significant difference was observed.

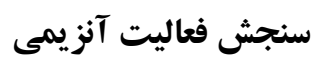

فعاليت آنزيمهاى سوير اكسيدديسمو تاز، آسكوربات براكسيداز و كاتالاز با توجه به تغييرات جذب و ازطريق فرمول زير محاسبه

$$
\begin{aligned}
& \text { از طرف ديخر، براى بررسى عملكرد آنزيمى كياه در اثر تنش } \\
& \text { سرمايى، فعاليت بيولوزيكى و فعاليت ويزه برخى آنزيمهاى مهم }
\end{aligned}
$$

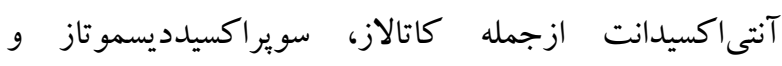

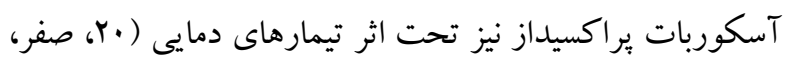

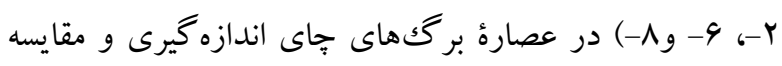

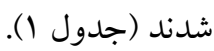




$$
\text { آنزيم آسكوربات يراكسيداز }
$$

بررسى فعاليت آنزيم آسكوربات براكسيداز در برگكهاى جـاى نشان داد كه فعاليت اين آنزيم با كاهش دما افزايش مىيابد؛ بـهـ طورى كه فعاليت تا دماى ه- درجه سانتى گر اد بهتدريج افزايش بيدا مى كند و در اين دما با • • م / • ميكرومول بر دقيقـه بيشترين فعاليت را دارد (شكل r).
تفاوت جذب در دقيقه در طول موج هـه نانومتر (A505/min) از طرفى، مقدار كل يروتئين در محلول استخراجشده بركَهـاى جاى باتوسط روش بر ادفورد اندازهگيرى شـده بـود و مقـدار آن با كاهش دما افزايش نشان داد. نتايج بهدست آمده بـراى فعاليـت كل نيز همراه با فعاليت ويثه هـر سـه آنزيم در جـدول ا آورده شدهاند.

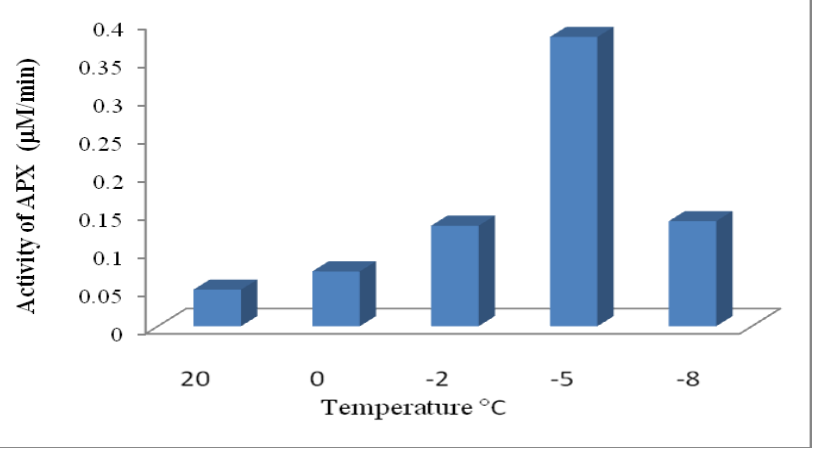

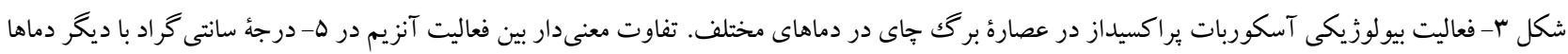

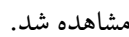

Fig. 3. Biological activity of Ascorbate peroxidase in tea leaf extracts at different temperatures. A significant difference was observed between $-5^{\circ} \mathrm{C}$ and other temperatures.

$$
\text { جدول 1- اثر دما بر فعاليت كل و فعاليت ويثٔه آنزيمهاى كاتالاز، سوير اكسيدديسمو تاز و آسكوربات يراكسيداز. }
$$

Table 1. The effect of temperature on total and specific activity of catalase, superoxide dismutase and Ascorbate

\begin{tabular}{|c|c|c|c|c|}
\hline فعاليت ويزه ( & فعاليت ( & $\begin{array}{c}\text { مقدار كل يروتئين } \\
\text { (mg/ml) }\end{array}$ & دما (C) & آنزيم \\
\hline$|/ 4|$ & r/9Y & $r / \Delta \Delta$ & r. & \multirow[t]{5}{*}{ 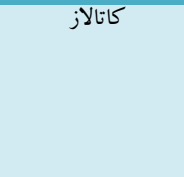 } \\
\hline$r / \cdot 9$ & $9 / 1 V$ & $r / 9 \Delta$ & . & \\
\hline$Y / T F$ & $\mathrm{~V} / \mathrm{TA}$ & $r / Y \Delta$ & $-Y$ & \\
\hline$r / A V$ & $11 / r \Delta$ & $F / \Delta \Delta$ & $-\Delta$ & \\
\hline $1 / 49$ & $\mathrm{~V} / \mathrm{II}$ & $F / v \Delta$ & -1 & \\
\hline$\cdot / \cdot 11$ &.$/ \cdot 4 \lambda$ & $r / \Delta \Delta$ & $r$. & \multirow[t]{5}{*}{ آسكوربات يراكسيداز } \\
\hline.$/ Y^{\prime}$ & $\cdot / \cdot V Y$ & $r / 9 \Delta$ & · & \\
\hline 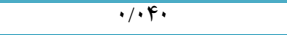 &.$/ I r Y$ & $r / Y \Delta$ & $-r^{2}$ & \\
\hline$\cdot / \cdot \Delta \mu$ & $\cdot / \Gamma \Lambda$ & $F / \Delta \Delta$ & $-\Delta$ & \\
\hline 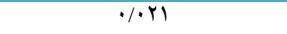 & $\cdot / I r \wedge$ & $F / V^{F}$ & $-\wedge$ & \\
\hline$\cdot / r / Q$ & $\cdot / \Delta \Delta$ & $r / \Delta \Delta$ & r. & \multirow{5}{*}{ سوير اكسيد ديسموتاز } \\
\hline$\cdot / F M$ & $1 / F F$ & $r / 9 \Delta$ & . & \\
\hline$\cdot / 099$ & 1/AD & $r / Y \Delta$ & $-r$ & \\
\hline$\cdot / \mathrm{V} \cdot \Delta$ & $r / Y 1$ & $F / \Delta \Delta$ & $-\phi$ & \\
\hline.$/ 91 V$ & $F / r \Delta$ & $F / V^{F}$ & $-\Lambda$ & \\
\hline
\end{tabular}
peroxidase. 
محاسبه فعاليت ويزه در هر مورد با استفاده از فرمول ذيل و

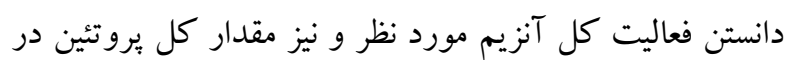
عصاره برگك هاى جاى انجام گرفت

Specific Activity (unit/mg) $=\frac{\text { Total activity }}{\text { Total protein }}$

\section{فعاليت ويزٔ آسكوربات ير اكسيداز}

نتايج نشان دادند كه فعاليت ويزٔة اين آنزيم نيز همانــد فعاليت

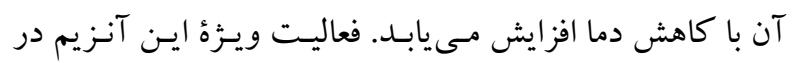

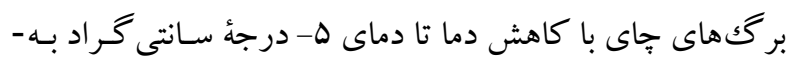

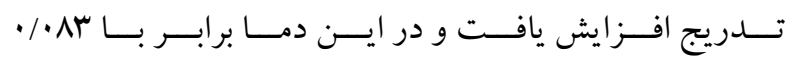

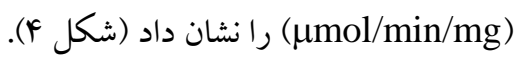

بررسى نتايج فعاليت كاتالاز نشان داد كـه فعاليـت آنزيم يـيش

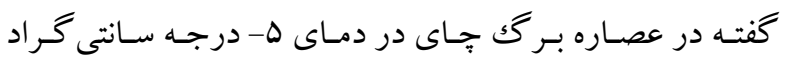
بيشترين مقدار و برابر با هـ/1/ميكرومول بر دقيقه است (جـدول

\section{فعاليت سوير اكسيد ديسموتاز}

آنزيم سو ير اكسيد ديسـموتاز نسبت بـه دوآنزيم آسكوربات

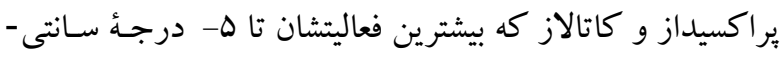

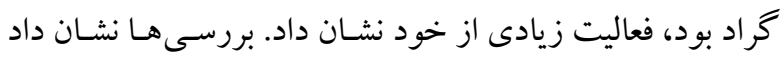

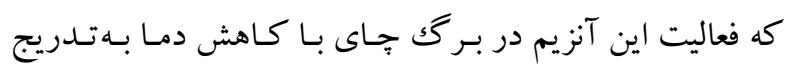

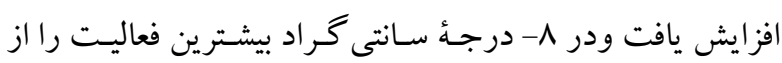

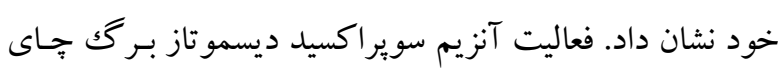

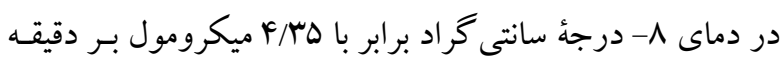
به دست آمد (جدول ().

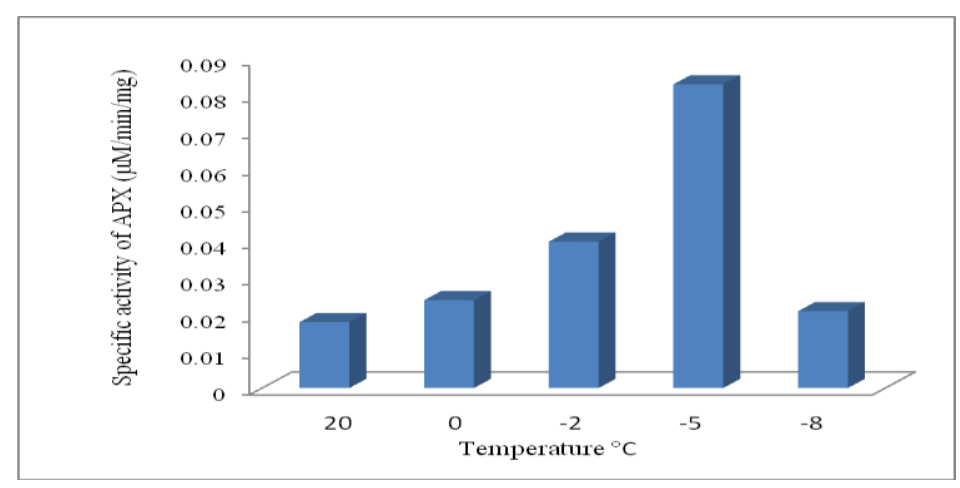

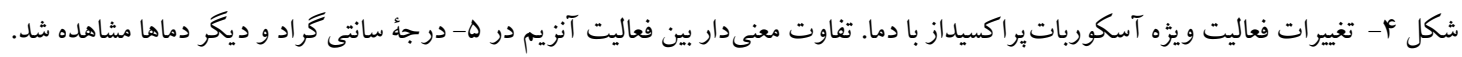

Fig. 4. Variations of specific activity of Ascorbate peroxidase according to temperature. A significant difference was observed between $-5^{\circ} \mathrm{C}$ and other temperatures.

براساس نتايج، كاتالاز برگك جـاى بيشترين فعاليـت ويتزه را در

فعاليت ويزه كاتالاز

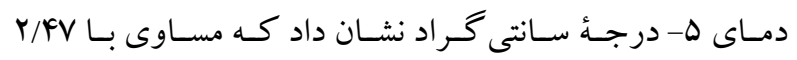

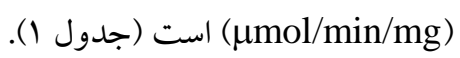
نتايج سنجش فعاليت ويزّه كاتالاز در برك جاى نشان نشان دادند كـه

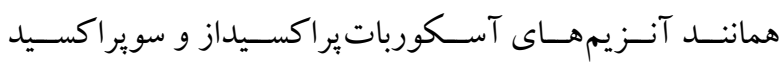

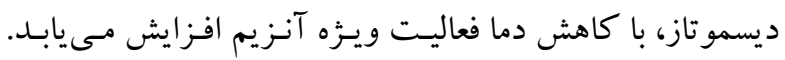


تهيهشده از بر گكهاى جاى، برخلاف بقيه، بعد از قرارگر فتن در

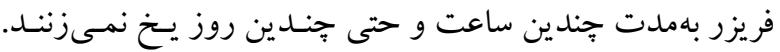

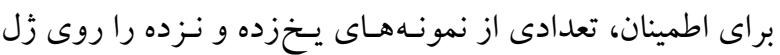

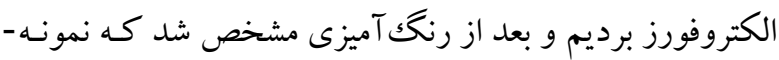

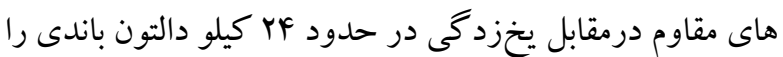
مىدهند كه اين باند در نمونههاى يخ زده مشاهده نمى شود.

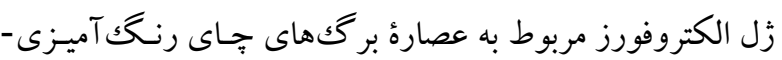

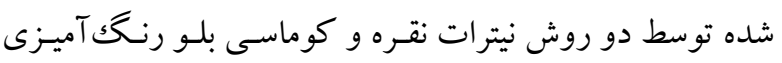

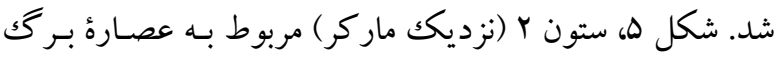

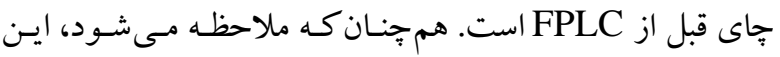
ستون وجود تعدادى يروتئين را نشان مىدهد كـه بـه دليل عـدم تخليص حاوى تعداد باندهاى زيادى اسـت. سـتونهـاى ب تـا 9

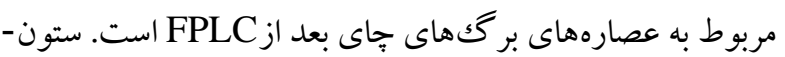

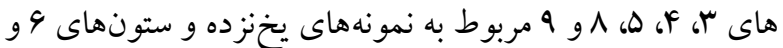

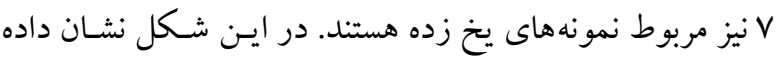

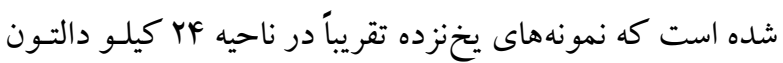
داراى باندى هستند كه اين باند در نمونههاى يخزده ديده نمى - تركي

\section{فعاليت مخصوص سوير اكسيدديسموتاز} در آزمايش هاى قبلى براى بررسى فعاليت آنزيمى، مشخص شد

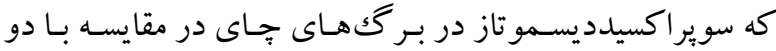
آنزيم كاتالاز و آسكوربات يراكسيداز در دمـاى بـايين تـرى (^درجه سانتى گراد) فعاليت از خود نشان مىدهد. ازطرفى، بررسى نتايج سنجش فعاليت ويزه اين آنزيم اثبات كننده اين واقعيت بود

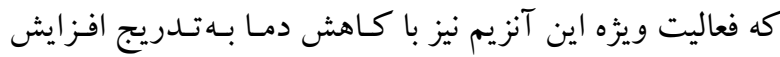

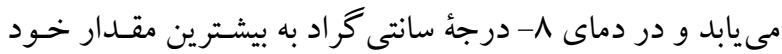
مى رسد. بر اساس نتايج حاصل از اين بخـش، فعاليـت ويـزّه ايـن

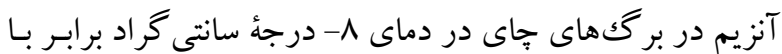
( مى شود (جدول ()).

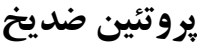

علاوهبرسنجش فعاليت آنزيمهاى درگير در فعاليت ضد يخى و

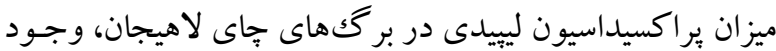
يروتئين ضد يخ غير آنزيمى نيز در آنها رديابى و توجيـه شـد.

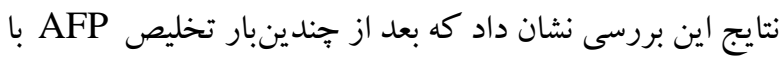

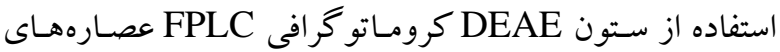

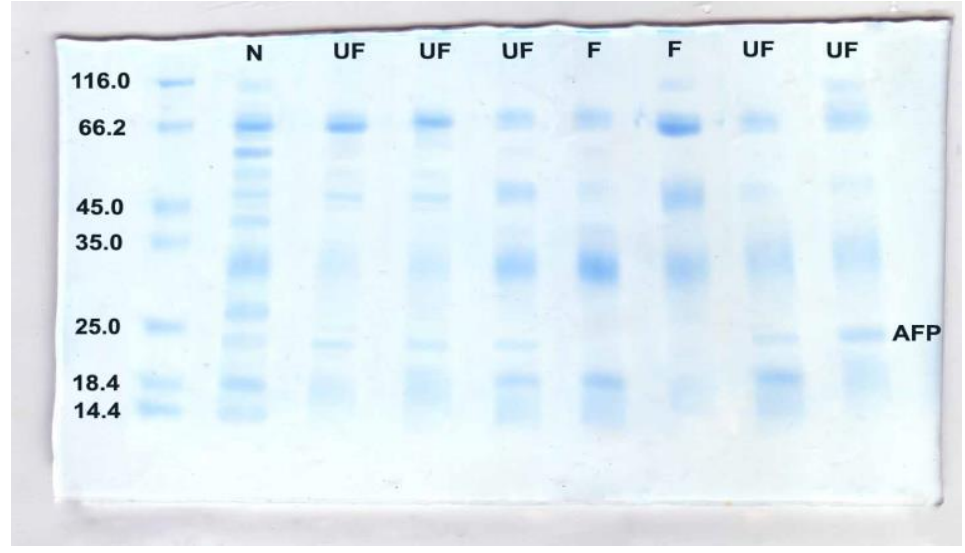

شكل ه- زل بلى اكريل آميد عصارة بركى هاى جاى رنك آميزى شده با كوماسى بريليانت بلو با استفاده از ستون دىاتيل آمينواتيل F= Frozen, UF= .FPLC

Fig. 5. Polyacryl amide gel stained with comassi brilliant blue using diethyl amino ethyl column in FPLC ( $\mathrm{F}=$ Frozen, $\mathrm{UF}=$ Unfrozen). 
در طى يخبندانهاى طبيعى، بر گكهاى گياهان هميشـهـبز مانتـد

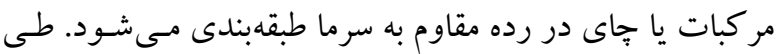

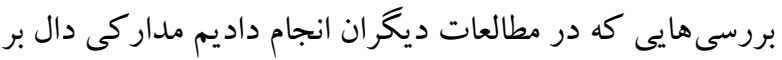
مقاومت سرمايى در گياه جاى ملاحظه نشد. بهنظر مسرسـد كـه

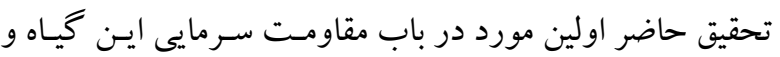

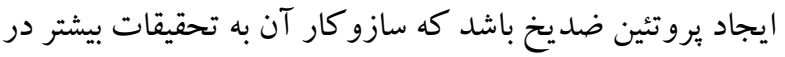
آينده نياز دارد. درهر حال، گزارش شده است كه برخى گياهـان

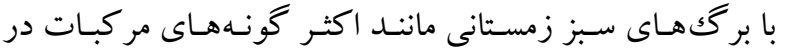
دماى • ا- درجهٔ سانتى گر اد بديده فراسردشدن را از خود نشـان مىدهند (Yelenosky \& Guy, 1982). از آنجايى كه گياهان داراى مكـان ثابـت هسـتند، جُنانجـه تحمـل

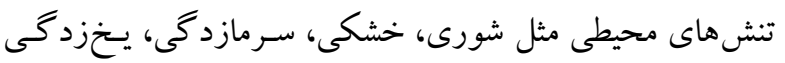

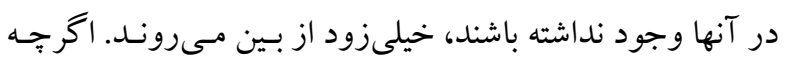

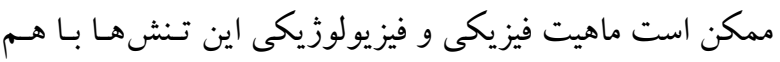

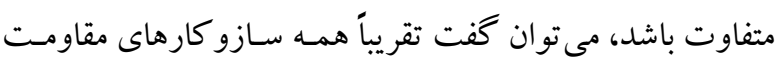

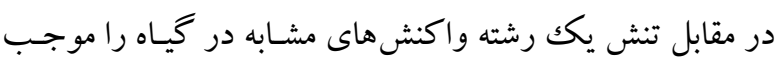

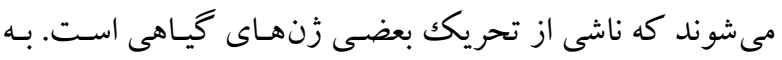

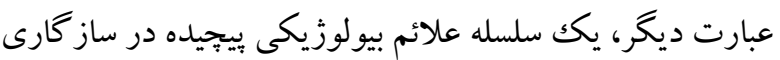

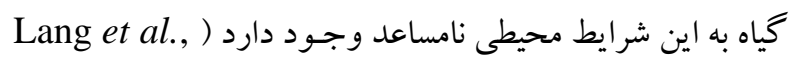
. (2005

در تحقيقات مشابه با تحقيق حاضر بيان شده است كه اغلب

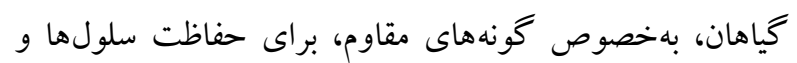
بافتهاى خود از استرسهاى اكسيداتيو متابوليتهاى ثانويه متعددى توليد مى كنند. براى مثال، در تأييد نتايج ما، تركيبات ايجاد شده در اثر تنشهاى سرمايى شامل قندها، آمينواسيدها،

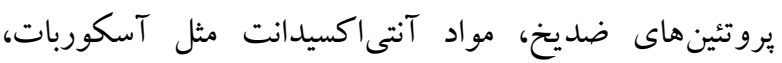

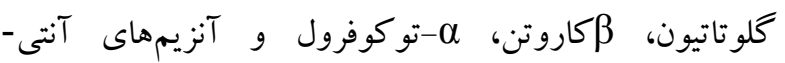
اكسيدانت ازجمله سويراكسيدديسموتاز (SOD)، كاتالاز

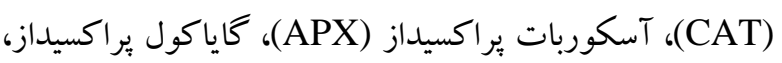

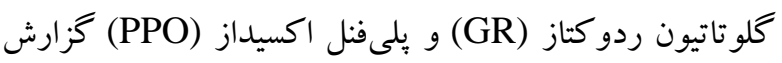
شدهاند (Gilmour \& Thomashow, 1991). بررسى برخى از اين تركيبات در تحقيق ما نشان دادند كه فعاليت آنزيمهاى
عمل تخليص يُروتئين AFP ازطريق كروماتو گرافى FPLC، علاوهبر ستون DEAE، با ستون Q- Sepharose نيز انجام كرفت. در اين مرحله براى بررسى و اطمينان بيشتر فقط نمونه-

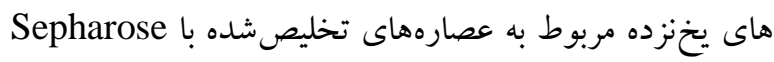

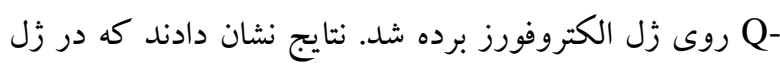

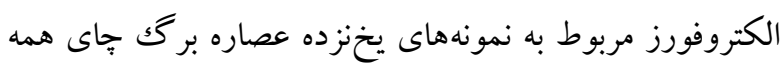

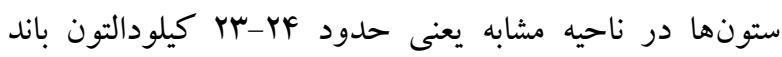

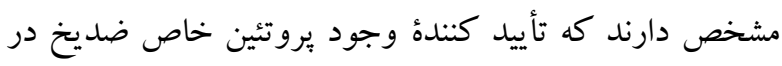

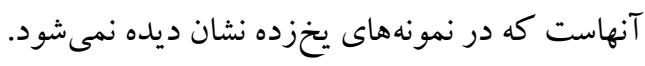

بحث

بديهى است كه مقاومت گياه جاى جهت سالمماندن در دماهاى

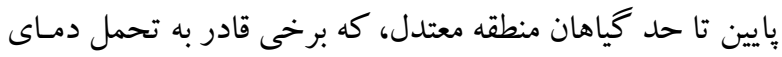

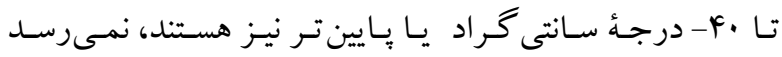

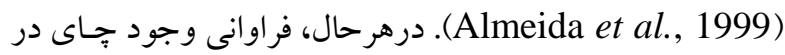

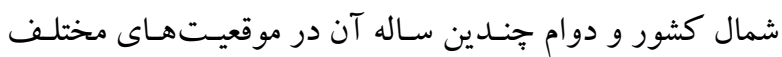

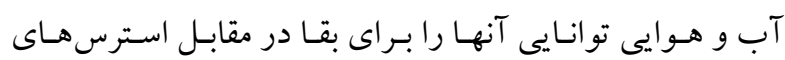

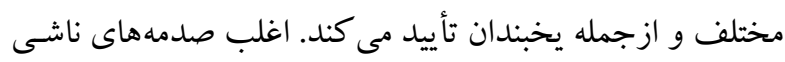

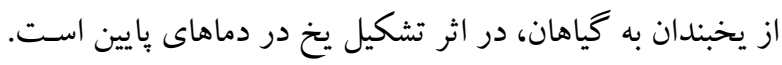

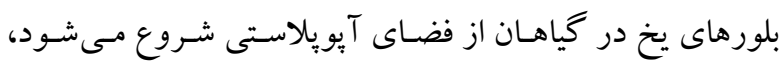

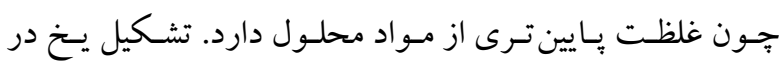

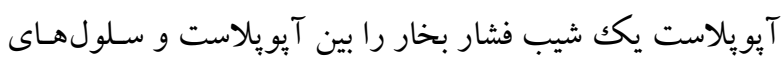

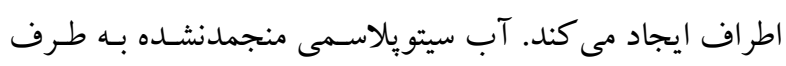

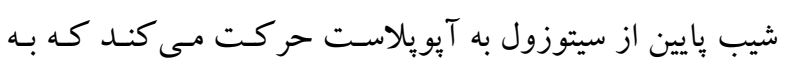
بزرگكشدن كريستالهاى يخ موجود منجر مىشود و سبب فشـار

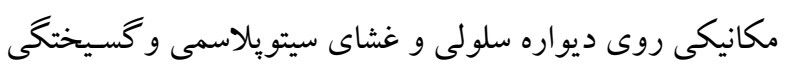
سلول مىشود (Yelenosky, 1985). ايجاد دماى ويزه كه در اثر تغيير نا گهانى آب و هـو إيش مهى-

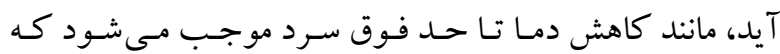

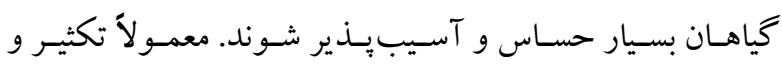

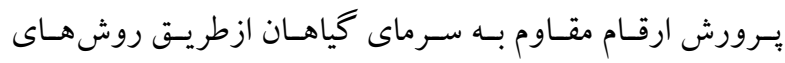

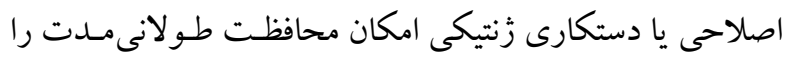

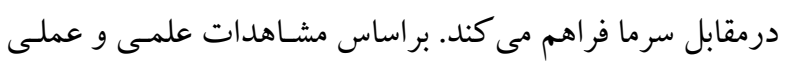


فعاليت APX تا دماى ه- درجةُ سانتى گر اد افزايش يافت. به اين

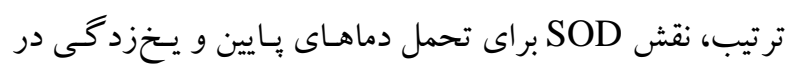

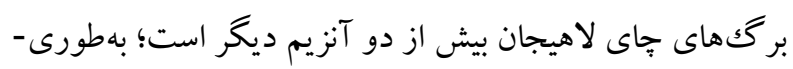

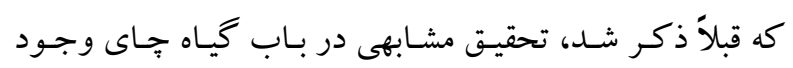

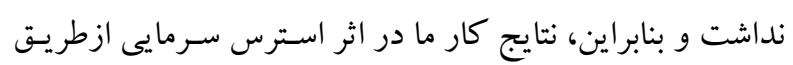

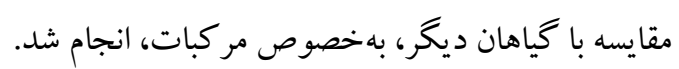

نتايج تحقيق در باب مر كبات نشان دادهاند كه فعاليت آنزيمهاى

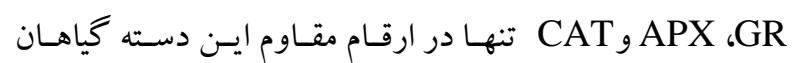
افزايش نشان مىدهنــ (Gilmour \& Thomashow, 1991). اين نتايج در باب آنزيمهاى آنتى اكسيدانت برخى مر كبات مسى -

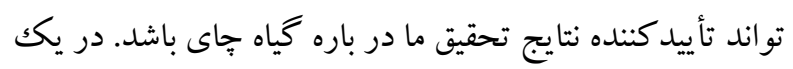
بررسى ديخر مشخص شد كـه سطح فعاليـت آنزيم كاتـالاز در

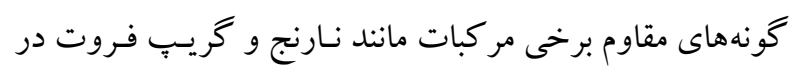

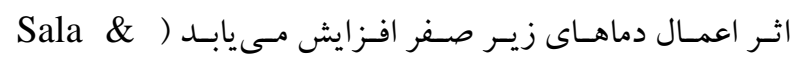

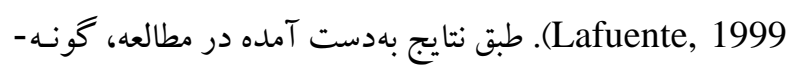

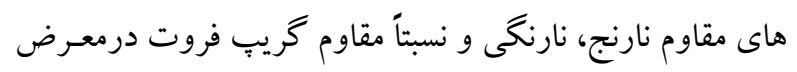

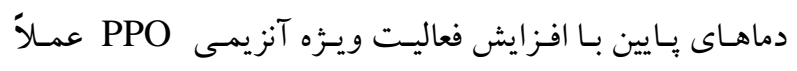

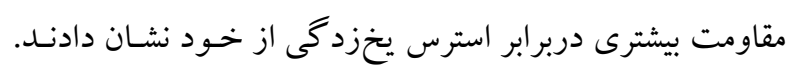

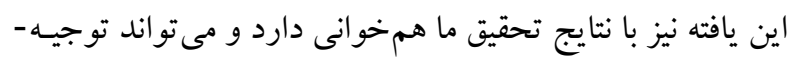

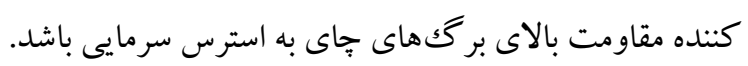

بررسى هاى نظرى ما بيان كنتـده ايـن بودنـــــــه اغلب مطالعـات

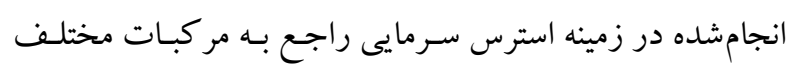

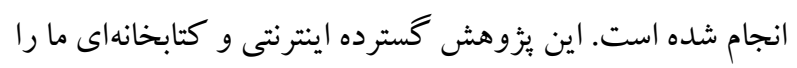

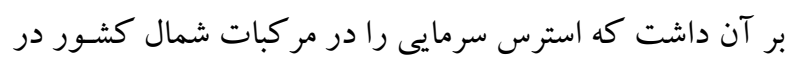

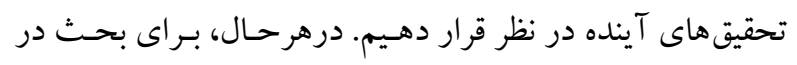

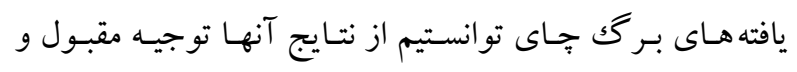

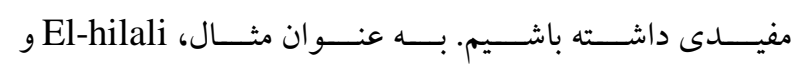
همكاران (2003) گزارش كردند كه ميزان فعاليت آنزيم

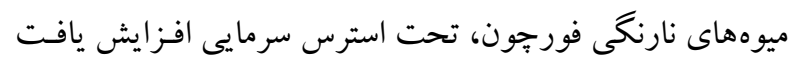

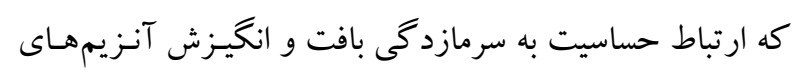

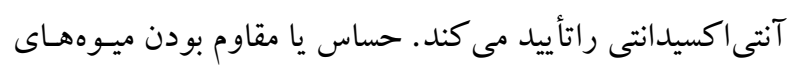

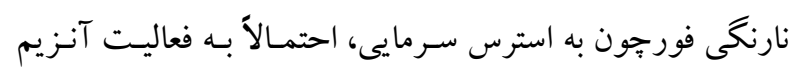

APX و در بركَهاى جاى در تيمارهاى دمايى

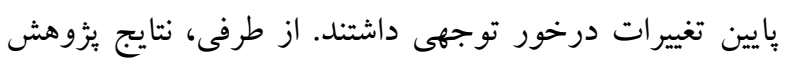

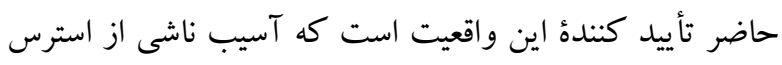

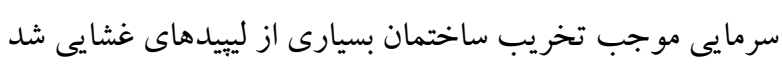

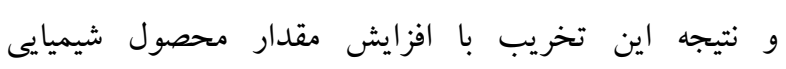
اكسيداسيون ليييدها يعنى مالون دى آلدئيد به تأييد رسيد.

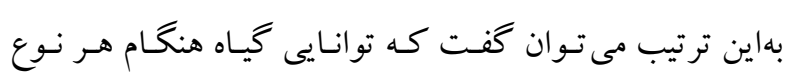

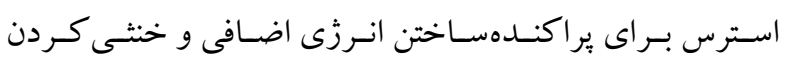

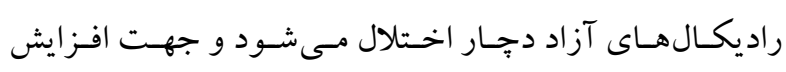
مقاومت و تحمل اين گونه استرسها ظرفيت آنتى اكسيدانتى خود أنس را بهسرعت افزايش مى دهند.

كاتالاز (CAT)، براكسيدازها (POX) و سوير اكسيد ديسموتاز

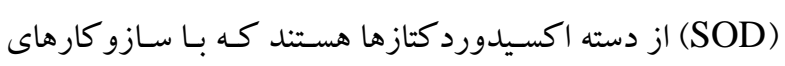
مشابه راديكالهاى آزاد ناشى از سـرمازدكى را مهار مهى كنتـد.

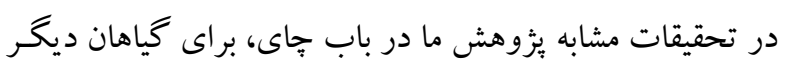

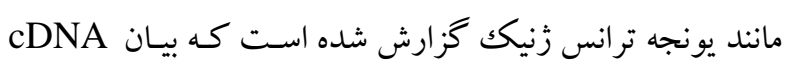

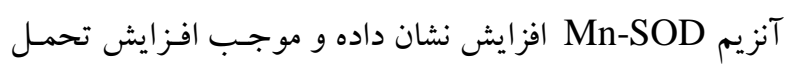

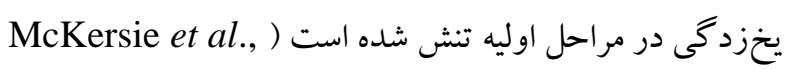

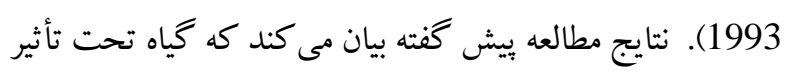

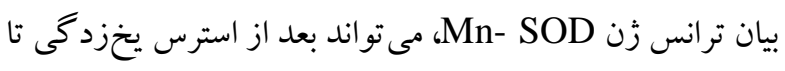

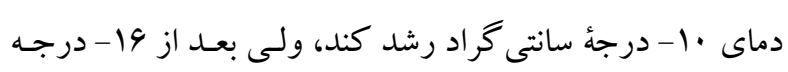

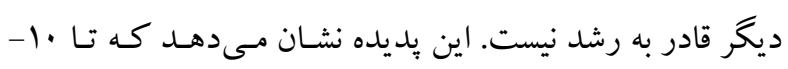

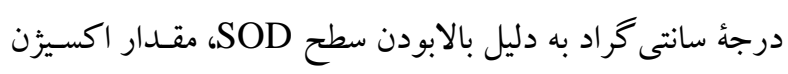

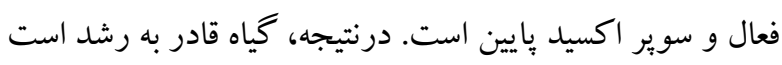

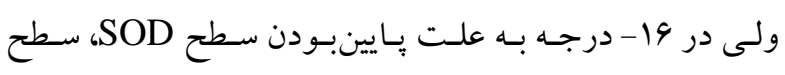

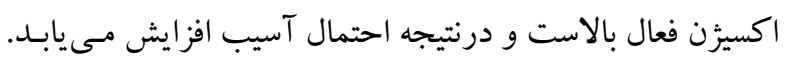

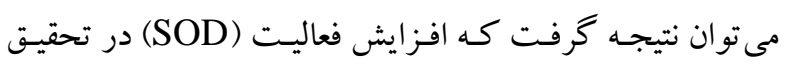

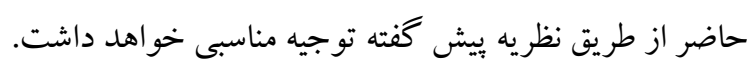
نتايج يزوهش حاضر نشان دادند كه فعاليت آنزيمهاى SOD،

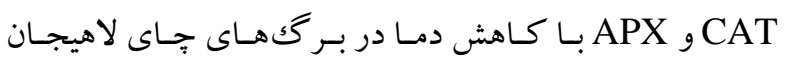

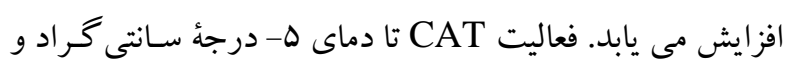
SOD 
در فر آيند ذوب - انجماد فعاليت خود را از سر بحيرد. اين نتايج

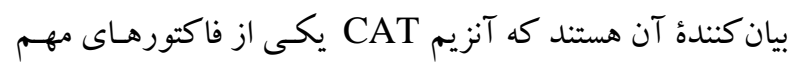

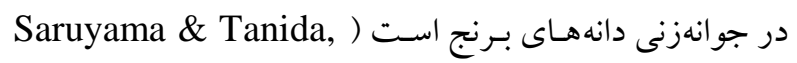

در بزوهشى ديخر درباب بـركَهـاى كيـاه جـو، كـه يـك دوره

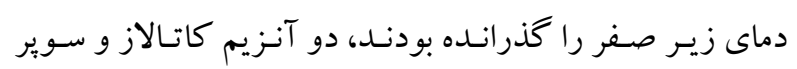

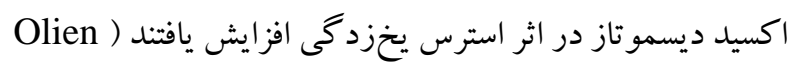

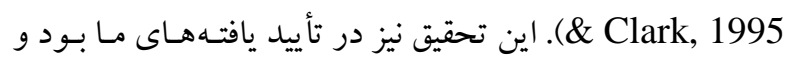

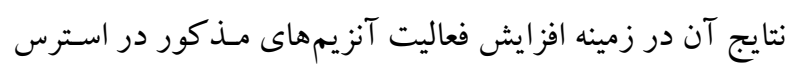

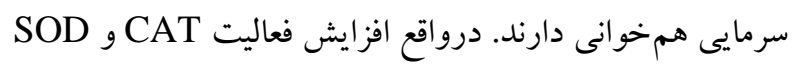

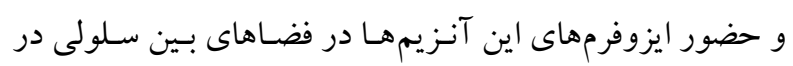

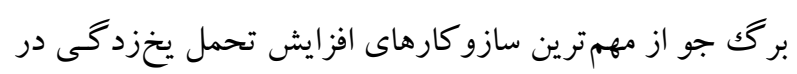

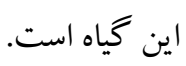

درنهايت مى توان اضـافه كرد كـه عـلاوهبر گيـاه جـاى در ايـن

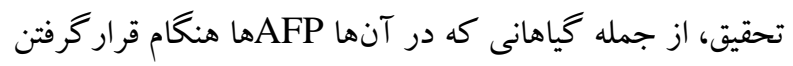

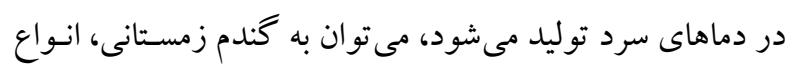

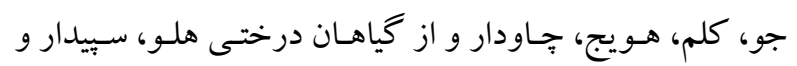
مركبات اشاره كرد (Griffith et al., 1997).

\section{نتيجه كيرى نهايى}

جاى گياهى مقـاوم و هميشهـسـبز اسـت كـه در نـواحى شـمالى

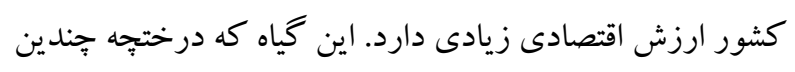

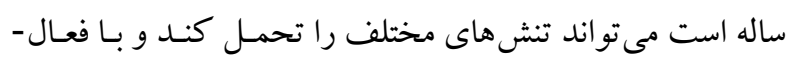

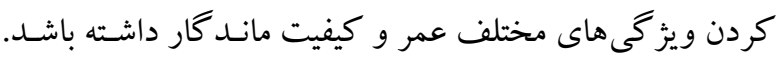

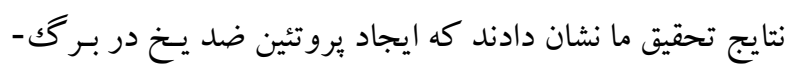

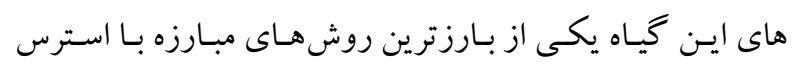

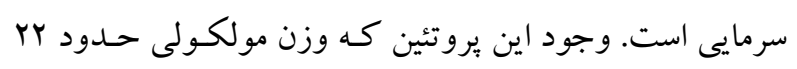

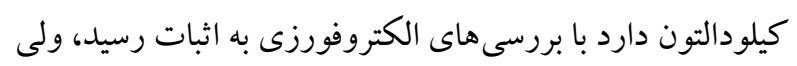

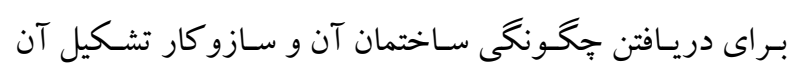

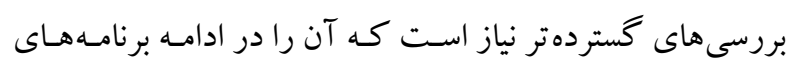

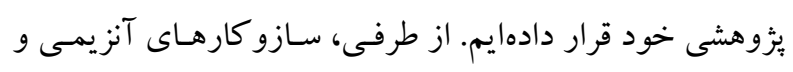

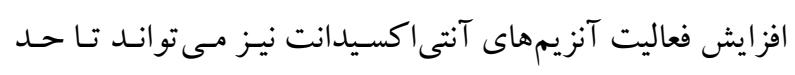
زيادى خطرها و آسيبهاى ناشى از كاهش دما را مرتفع كنند.
و متابوليسم براكسيد هيدروزن بستخى دارد. اين نتايج نيز

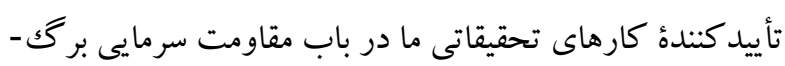

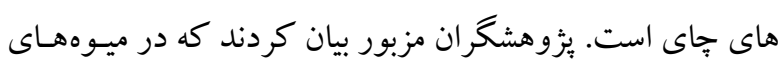
نارنكى فورجون كه استرس سرمايى ديده بودنـد فعاليـت آنزيم افز ايش يافت، درصورتى كه در ميوههايى كه تحت تأثير

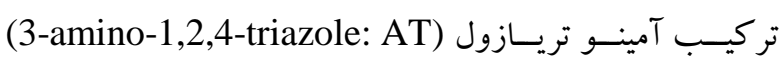

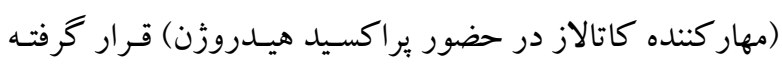

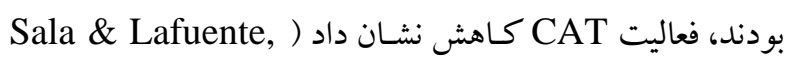

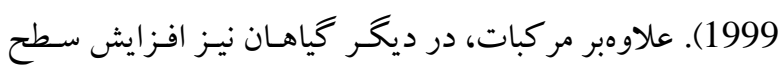

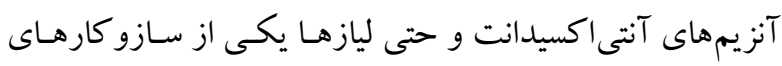

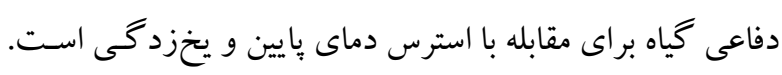

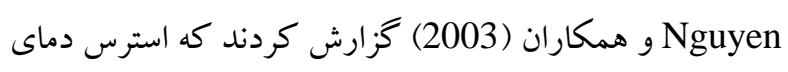

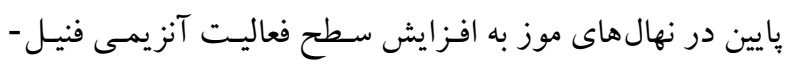

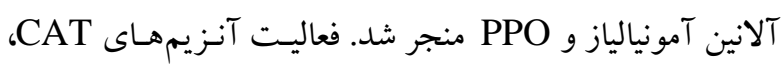

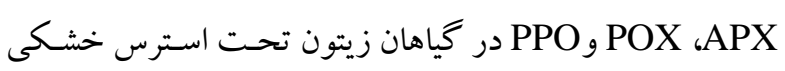

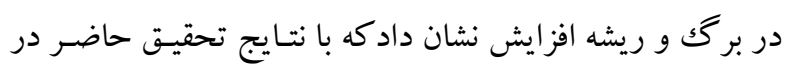

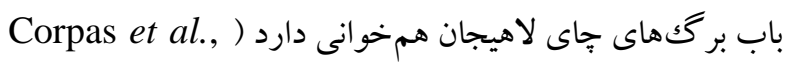

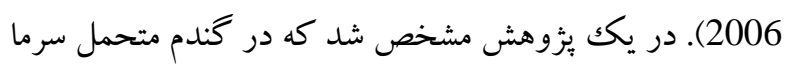

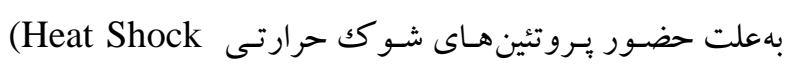
توانسايى ســرمازدخى افـز ايش يافــت Proteins: HSPs)

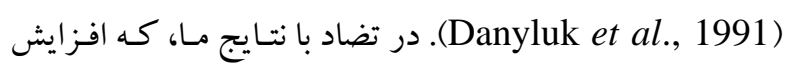

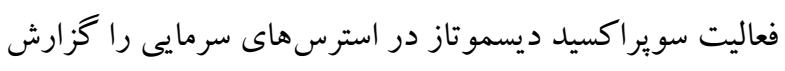

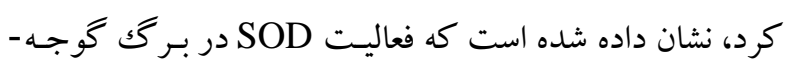

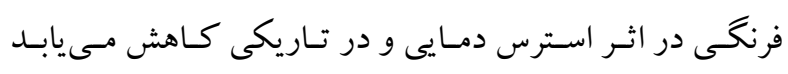

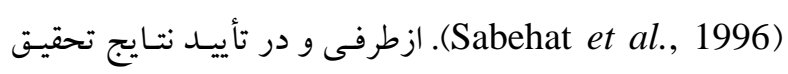
حاضر، Clare و همكارن (1984) نشان دادند كه در گياه مقاوم

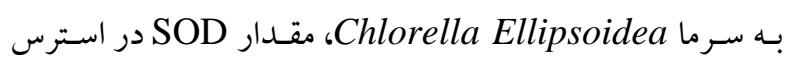

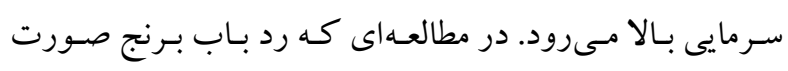

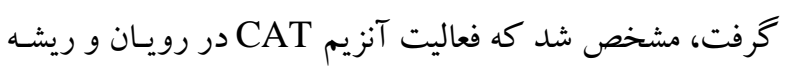

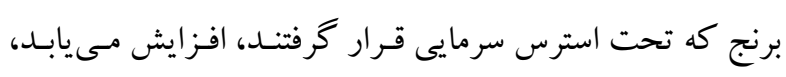

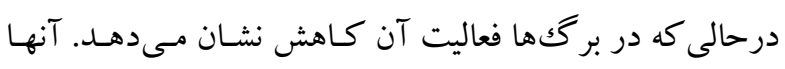

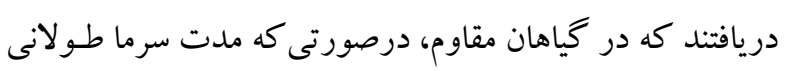

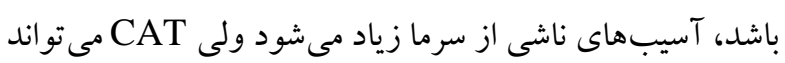




$$
\text { تحقيق ما افزايش مقدار مالون دى آلدئيد را در تنشهاى سرمايى كاد كهاد }
$$

\section{References}

Almeida, A.S., Cavieres, L.A. and Bravo, L.A. 1999. Freezing resistance of high-elevation plant species is not related to their height or growth-form in the central Chilean Andes. - Environmental and Experimental Botany 69: 273-278.

Alscher, R.G., Erturk, N. and Heath, L.S. 2002. Role of superoxide dismutases (SODs) in controlling oxidative stress in plants. - Journal of Experimental Botany 53: 1331-1341.

Bradford, M.M. 1976. Rapid and sensitive method for the quantitation of microgram quantities of protein utilizing the principle of protein-dye binding. - Anal. Biochem. 72: 248-254.

Bunkelmann, J.R. and Trelease, R.N. 1996. Ascorbate peroxidase. A prominent membrane protein in oilseed glyoxysomes. - Plant Physiol. 110: 589-598.

Burke, M.J., Gusta, L.V., Quamme, H.A., Weiser, C.J. and Li, P.H. 1976. Freezing and injury in plants. Annual Reviews in Plant Physiology 27:507-528.

Cattivelli, L. 2011. More cold tolerant plants for warmer world. - Plant Science 180: 1-2.

Clare, D.A., Rabinowitch, H.D. and Fridovich, I. 1984. Superoxide dismutase and chilling injury in Chlorella ellipsopides. - Arch. Biochem. Biophys. 231:158-163.

Corpas, F.J., Corpas, F.J., Fernández-Ocaña, A., Carreras, A., Valderrama, R., Luque, F., Esteban, F.J., Rodríguez-Serrano, M., Chaki, M., Pedrajas, J.R., Sandalio, L.M., del Río, L.A. and Barroso, J.B. 2006. The expression of different superoxide dismutase forms is cell-type dependent in olive (Olea europaea L.) leaves. - Plant Cell Physio. 47: 984-997.

Danyluk, J., Rassart E. and Sarhan, F. 1991. Gene expression during cold and heat shock in wheat. Biochem. Cell Biol. 69: 383-391.

El-hilali, F., Ati-oubahou, A., Remah, A. and Akhayat, O. 2003. Chilling injury and peroxidase activity changes in fortune mandarine fruit during low temperature storage. - BULG. J Plant Physiol. 29: 4454.

García-Varela, S. and Fermín, R. 2003. Freezing avoidance mechanisms in juveniles of giant rosette

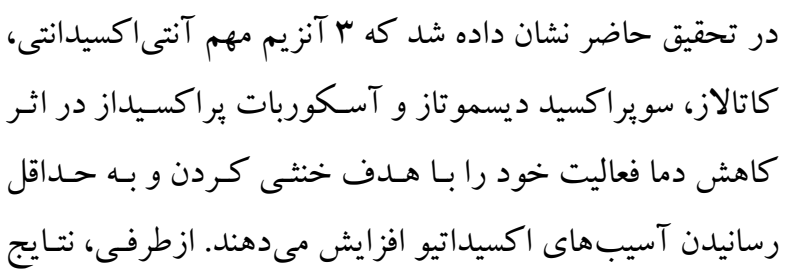

plants of the genus Espeletia. - Acta Oecologica 24: 165-167.

George, M.F. and Burke, M.J. 1984. Super cooling of tissue water to extreme low temperature in overwintering plants. - Trends in Biochemical Sciences 9: 211-214.

Gilmour, S.J. and Thomashow, M.F. 1991. Cold acclimation and cold-regulated gene expression in ABA mutants of Arabidopsis thaliana. - Plant Mol. Biol. 17: 1233-1240.

Graham, H.N. 1992. Green tea composition, consumption, and poly-phenol chemistry. - Preventive Medicine 21: 334-350.

Griffith, M., Antikainen, M., Hon, W.C., PihakaskiMaunsbach, K., Yu, X.M., Chun, J.U. and Yang, D.S.C. 1997. Antifreeze proteins in winter rye. Physiologia Plantarum 100: 327-332.

Lang, P.C.K., Zhang, R.C., Ebel Dane, F. and Dozier, W.A. 2005. Identification of cold acclimated genes in leaves of citeus unshiu. by mRNA differential display. - Gene 359: 111-118.

Liu, S.C., Lin, J.T., Wang, C.K., Chen, H.Y. and Yang, D.J. 2009.Antioxidant properties of various solvent extracts from lychee (Litchi chinenesis Sonn.) flowers. - Food Chem. 114: 577-581.

Lynch, D.V. and Steponkus, P.L. 1987. Plasma membrane lipid alterations associated with cold acclimation of winter rye seedlings (Secale cereale $\mathrm{L}$. cv. Puma). - Plant Physiol. 83: 761-767.

Maehly, A.C. and Chance, B. 1954. The assay of catalases and peroxidases. - Methods of Biochemical Analysis 1: 357-424.

McKersie, B.D.M., Chen, Y., de Beus, M., Bowley, S.R., Bowler, C., Inzé, D., D'Halluin, K. and Botterman, J. 1993. Superoxide dismutase enhances tolerance of freezing stress in transgenic alfalfa (Medicago sativa L.). - Plant Physiol. 103: 1155-1163.

Nguyen, T.B.T., Ketsa, S. and Doorn, W.G.V. 2003. Relationship between and the activities of polyphenol oxidase and phenylalnine ammonia-lyase in banana 
peel during low temperature storage. - Postharvest Biology and Technology 30:187-193.

Olien, C.R. and Clark, J.L. 1995. Freeze-induced changes in carbohydrates associated with hardiness of barley and rye. - Crop Sci. 35:496-502.

Prasad, T.K. 1997. Role of catalase in inducing chilling tolerance in pre-emergent maize seedlings. Plant Physiol. 114:1369-1376.

Sabehat, A., Weiss, D. and Lurie, S. 1996. The correlation between heat-shock protein accumulation and persistence and chilling tolerance in tomato fruit. Plant Physiol. 110: 531-537.

Sala, J.M. and Lafuente, M.T. 1999. Catalase in the heat-induced chilling tolerance of cold-stored hybrid
Fortune mandarin fruits. - J. Agric Food Chem. 47: 2410-2414.

Saruyama, H. and Tanida, M. 1995. Effect of chilling on activated oxygen-scavenging enzymes in low temperature-sensitive and tolerant cultivars of rice (Oryza sativa L.). - Plant Sci. 109: 105-113.

Yelenosky, G. 1985. Cold hardiness in citrus. In: Janick, G. (ed). Horticultural Review. - Timber Press. pp: 201-238.

Yelenosky, G. and Guy, C.L. 1982. Seasonal variations in physiological factors implicated in cold hardiness of citrus trees. - Academic Press New York. pp: 561-573.

Sariri, R., Raeofi Masooleh, A. and Bakhshi Khaniki, G.R. 2016. The effect of cold temperature on oxidative damage and activity of oxidative enzymes in tea leaves from northern Iran. - Nova Biologica Reperta 2: 298-311.

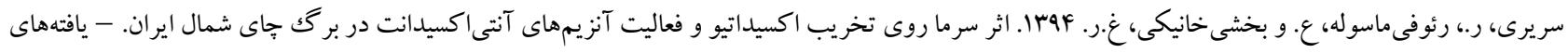
نوين در علوم زيستى ب: الب- 